\title{
Inhaltsverzeichnis / Contents
}

Vorwort / Preface

GABY WAXENBERGER, HANS SAUER \& KERSTIN KAZZAZI..

Phonetische Termini und Symbole / Phonetic Terms and Symbols ................................. xiii

Abkürzungsverzeichnis / List of Abbreviations ............................................................... xvii

Liste der Tabellen / List of Tables .................................................................................

Liste der Abbildungen / List of Figures ......................................................................... xxii

Liste der Karten / List of Maps ...................................................................................... xxiii

I. Die älteste Überlieferung / The Earliest Tradition ..............................................

Das Bild, die Silbe und die Laute: Keilschrift und Hieroglyphen Anatoliens zwischen dem 2. und 1. Jahrtausend vor Christus

Image, Syllable and Sounds: Cuneiform Script and Hieroglyphs in Anatolia between the 2nd and the 1st Millennium B.C.

PAOLA COTTICELli-KurRas \& FEDERICO GIUSFREDI

\section{Germanische Sprachen im Mittelalter und ihre Verschriftung /}

Germanic Languages in the Middle Ages and How They Were Written.

Die phonologischen Systeme des mittelalterlichen Englischen und Deutschen, des Altnordischen und die sie überliefernden Scriptae: ein phonologisch-graphematischer Vergleich

The Phonological Systems of Medieval English and German and Old Norse, and the Corresponding Spelling Systems: A Phonemic-Graphemic Comparison

KLAUS DIETZ

Zur Graphematik des $i$-Umlauts im Altenglischen und Althochdeutschen How i-Mutation was Indicated in Old English and Old High German Spelling ANNINA SEILER

The Notation of Umlaut Vowels in the Old Icelandic Grammatical Treatises FABRIZIO D. RASCHELLÀ.....

Abandon the Grapheme? The Study of Middle English Manuscript Texts and Why the Concept "Grapheme" is Not a Promising Start

KENNA L. OLSEN

Yogh/Zed Graphic Variation in Cotton Nero A.x. and the Concept of the Grapheme MURRAY MCGILLIVRAY 
III. Runen und Runenkunde / Runes and Runology

The (Dis-)Ambiguity of the Grapheme in the High Medieval Runic Script

TERJE SPURKLAND

Graphem-Phonem-Korrespondenz im jüngeren fupark: Sonderfall Runenprovinz Gotland

Grapheme-Phoneme Correspondences in the Younger Fupark: The Special Case of the Runic Province Gotland

Alessia BAUER

Anglo-Saxon Runic Writings and Philological Issues

ALFRED BAMMESBERGER

The Role of Memory in Old English Runic Inscriptions as a Model for Reading

Selected Norwegian Rune-Sticks

VICTORIA SYMONS

The Development of the Old English fuporc

GABY WAXENBERGER

IV. Spiele im Mittelalter und im Internet: ihre Sprache und ihre Terminologie / Medieval Games and Internet Games: Their Language and Terminology

Tefldo i Tuni, Teitir Voro - Chess and Hnefatafl in the North Michael SCHULte.

Graphemics and Orthography in Massively Multi-Player Online Role-Playing Games:

Use and Recognition

OLIVER M. TRAXEL

V. Anhang / Appendix

Karten / Maps

Glossar / Glossary 309

Index / Index

Die Beiträgerinnen und Beiträger / Notes on Contributors. 